\title{
Analisis Pendapatan Usahatani Sawi di Desa Humusu Oekolo Kecamatan Insana Utara Kabupaten Timor Tengah Utara
}

\author{
Agustinus Nubatonis ${ }^{\mathrm{a}}$ \\ ${ }^{a}$ Fakultas Pertanian, Universitas Timor, Kefamenanu, TTU - NTT, 85613, Indonesia.
}

\section{Article Info}

\section{Article history:}

Received 1 Juni 2015

Received in revised form 1 Juli 2015

Accepted 6 Oktober 2015

\section{Keywords:}

Analisis Pendapatan

Sawi

Insana Utara

\begin{abstract}
Abstrak
Penelitian dengan judul "Analisis Pendapatan Usahatani Sawi Di Desa Humusu Oekolo Kecamatan Insana Utara Kabupaten Timor Tengah Utara bertujuan untuk: 1) mengetahui besar pendapatan usahatani sawi di Desa Humusu Oekolo Kecamatan Insana Utara Kabupaten Timor Tengah Utara, dan 2) mengetahui kelayakan usahatani sawi di Desa Humusu Oekolo Kecamatan Insana Utara Kabupaten Timor Tengah Utara. Penelitian dilaksanakan di desa Humusu Oekolo kecamatan Insana Utara kabupaten Timor Tengah Utara, pengambilan data dilakukan pada bulan April 2013. Penentuan sampel menggunakan teknik quota sampling (jatah) sebanyak 30 orang petani sawi. Data yang dikumpulkan berupa data primer dan data sekunder kemudian ditabulasi dan dianalisis sesuai dengan tujuan yang ingin dicapai yakni untuk mengetahui besarnya pendapatan usahatani sawi menggunakan analisis pendapatan dan untuk mengetahui kelayakan usahatani saw menggunakan analisis return cost ratio (R/C). Hasil penelitian menunjukan bahwa: 1) pendapatan usahatani sawi sebesar Rp 250.000/responden atau sebesar Rp. 113.636,36,-/are, dan 2) RC ratio sebesar 3,27. Artinya secara ekonomi usahatani sawi di desa Humusu Oekolo secara ekonomi menguntungkan, sehingga layak dilanjutkan. @2016 dipubikasikan oleh Agrimor.
\end{abstract}

\section{Pendahuluan}

Sawi merupakan jenis sayuran yang banyak manfaatnya bagi kehidupan manusia, seperti sangat baik untuk menghilangkan rasa gatal di tenggorokan pada penderita batuk, penyembuh penyakit kepala, bahan pembersih darah, memperbaiki fungsi ginjal, serta memperbaiki dan memperlancar pencernaan.

Manfaat sawi yang sangat besar sehingga banyak dibutuhkan oleh masyarakat. Ini merupakan peluang usaha bagi petani sebagai sumbe pendapatan dengan berusaha meningkatkan produksinya seoptimal mungkin. Ha yang perlu mendapat perhatian petani adalah dasar usahatani, di antaranya pengolahan tanah, pemupukan, pengelolaan air, penyemaian benih, penanaman, pemeliharaan tanaman, pemungutan hasil, penanganan hasil juga perlu pemahaman analisis usaha bila tujuan bertanam untuk dijual (Sunarjono, 2002).

Sawi telah diproduksi oleh petani di Kecamatan Insana Utara Kabupaten Timor Tengah Utara (TTU). Data produksi lima tahun terakhir (tahun 2006 sampai dengan tahun 2010) menunjukan bahwa selalau berfluktuasi dengan kecenderungan semakin menurun. Produksi sawi pada tahun 2006 sebesar 58 ton sedangkan produksi sawi pada tahun 2010 sebesar 11 ton atau mengalam penurunan sebesar $81,00 \%$. Ini berarti rata-rata penurunan produksi setiap tahun sebesar 20,25\%. Produksi sawi di Kecamatan Insana Utara dari tahun 2006 sampai dengan tahun 2010 ditunjukkan pada Tabel 1.

\begin{tabular}{ccc} 
Tabel 1. Produksi Sawi di Kecamatan Insana Utara Tahun 2006-2010 \\
\hline Tahun & Produksi (ton) & Perkembangan (\%) \\
\hline 2006 & 58 & \\
2007 & 42 & $-27,59$ \\
2008 & 21 & $-50,00$ \\
2009 & 20 & $-4,76$ \\
2010 & 11 & $-45,00$ \\
\hline
\end{tabular}

Sumber: BPS Kab. TTU 2007, 2008, 2009, 2010, 2011.

Desa Humusu Oekolo merupakan sentra produksi sawi di Kecamatan Insana Utara mempunyai kontribusi terbesar dalam pembentukan produksi saw Kecamatan Insana Utara (hasil survei awal).

Produksi sawi membutuhkan berbagai korbanan atau faktor produksi seperti tanah atau lahan, tenaga kerja dan modal yang digunakan untuk pengadaan berbagai sarana produksi, seperti pengadaan benih, pupuk, pestisida, dan lain lain. Berbagai korbanan tersebut jika dinilai dengan uang akan membentuk sejumlah biaya baik biaya tetap maupun biaya variabel. Keberhasilan usahatan sawi tidak terlepas dari pengelolaan usahatani. Menurut Soeharjo dan Patong (1978) pengelolaan usahatani meliputi kemampuan petani dalam menentukan dan mengkoordinasikan faktor-faktor produksi yang bermacam-macam seefektif mungkin sehingga proses produksi pertanian memberikan hasil yang baik Kemampuan mengelola usahatani bergantung pada pengalaman dan pendidikan petani. Menurut Hernanto (1995) bahwa makin tinggi tingkat pendidikan dan pengalaman maka pengelola usahatani akan lebih berhati-hati dan memperhitungkan resiko yang dihadapi, sehingga dapat memilih alternatif dengan resiko yang rendah. Sangat disayangkan tingkat pendidikan formal petan sangat rendah dan pengalaman petani didominasi oleh warisan orang tua sehingga dapat dikatakan adopsi dan inovasi teknologi usahatani sawi di kecamatan Insana Utara masih rendah.

Banyak potensi yang dimiliki Desa Humusu Oekolo belum dikelola secara maksimal, karena masih banyak penduduk Desa Humusu Oekolo yang beranggapan bahwa usahatani sawi tidak menjanjikan keuntungan bila dibandingkan dengan usahatani padi sawah. Potensi ketersediaan air yang cukup untuk usahatani sawi di musim kemarau dan ketersediaan lahan yang cukup luas, namun selalu dipaksakan untuk usahatani padi sawah. Selain itu terdapat potens tenaga kerja dalam keluarga, namun usahatani sawi didominasi oleh tenaga kerja wanita dengan skala usaha pada luasan lahan yang kecil. Selain potensi domestik terdapat pula potensi dari luar keluarga tani, seperti ketersediaan bibit berlabel, pupuk dan obat-obatan sampai ke tingkat petani.

Sejauh ini belum dilakukannya analisa usahatani yang berkaitan dengan pendapatan usahatani sawi maka penelitian ini dilakukan dengan judul "Analisi Pendapatan Usahatani Sawi di Desa Humusu Oekolo Kecamatan Insana Utara Kabupaten Timor Tengah Utara.

\section{Metode}

Penelitian dilaksanakan di desa Humusu Oekolo kecamatan Insana Utara kabupaten TTU, pengambilan data dilakukan pada bulan April 2013. Penentuan sampel menggunakan teknik quota sampling (jatah) sebanyak 30 orang petani sawi.

Data yang dikumpulkan berupa data primer dan data sekunder. Data primer diperoleh melalui wawancara langsung dengan responden yang berpedoman pada kuisioner. Sedangkan data sekunder diperoleh dari instasi terkait. Data yang dikumpulkan ditabulasi dan dianalisis menggunakan analisis pendapatan dan analisis keuntungan relatif usahatani sawi maka digunakan analisis $\mathrm{R} / \mathrm{C}$ sesuai petunjuk Soekartawi (1993).

\section{Hasil dan Pembahasan}

3.1 Pendapatan Usahatani Sawi

Pendapatan usahatani sawi adalah selisih antara penerimaan dari usahatani sawi dengan semua biaya yang dikorbankan dalam usahatani sawi.

a. Biaya Usahatani Sawi

Biaya usahatani sawi adalah korbanan yang dinilai dengan uang dalam usahatani sawi. Dalam penelitian ini, tidak seluruh korbanan dinyatakan sebagai biaya. Korbanan yang diperhitungkan sebagai biaya adalah korbanan berupa uang tunai oleh petani selama proses produksi usahatani sawi. Sarana produksi yang digunakan dalam usahatani sawi yaitu sarana produksi tetap dan sarana produksi tidak tetap.

Sarana produksi tetap berupa peralatan pertanian, seperti linggis, pacul, parang, tajak, ember, gayung dan pisau. Sarana produksi tetap lain yaitu tanah atau lahan. Sarana produksi tetap tersebut tidak dinyatakan sebagai biaya tetapi sebagai sumbangan terhadap produksi usahatani sawi, karena sarana produks tersebut milik sendiri yang keberadaannya sudah lama dan diperuntukan bag berbagai usaha atau kegiatan dari petani. Sarana produksi berupa peralatan prosentase penggunaan untuk usahatani sawi sangat sedikit dan mereka tidak mengganggap itu sebagai biaya. Demikain juga tanah atau lahan sesungguhnya digunakan untuk usahatani padi sawah untuk lahan sawah dan pekarangan untuk usahatani jagung, labu dan palawija dimusim hujan. Penggunaan lahan untuk usahatani sawi pada musim kemarau dan air irigasi tidak mencukupi untuk usahatani padi sawah. Pajak Bumi dan Bangunan (PBB) dinyatakan sebaga biaya untuk usahatani padi sawah untuk lahan sawah dan pekarangan dinyatakan sebagai pajak atas rumah tempat tinggal petani. Menurut Tohir (1983) bahwa tanah dalam uahatani apa bila dipandang sebagai modal, maka kepada tanah itu diberikan bunga tanah (sewa tanah) dalam perhitungan. Sebaliknya tanah dianggap sebagai alat untuk memproduktifkan tenaga kerja petani dan anggota keluarganya, maka tanah dalam perhitungan usahatani tidak diberikan imbalan. Jadi dapat dikatakan bahwa tanah yang digunakan adalah untuk memanfaatkan tenaga kerja petani dan keluarganya.

Sarana produksi tidak tetap meliputi tenaga kerja, tali, benih, pupuk. Sarana produksi tidak tetap yang dinyatakan sebagai biaya yaitu pengadaan benih dan pupuk urea. Hasil penelitian menunjukan bahwa tenaga kerja dalam usahatan sawi berasal dari dalam keluarga. Terhadap tenaga kerja tersebut, petani tidak mengeluarkan uang sebagai biaya tenaga kerja. Menurut Mubyato (1995) tenaga kerja yang berasal dari keluarga petani merupakan sumbangan keluarga kepada produksi pertanian secara keseluruhan dan tidak pernah dinilai dengan uang.

Tali yang dimaksud adalah tali gebang (gebana, $s p$ ) diambil secara gratis dari alam, sehingga ini tidak dinyatakan sebagai biaya. Tali tersebut digunakan 
untuk mengikat sayur sawi. Benih sawi dan pupuk urea diperoleh dengan cara membeli secara tunai dari pedagang saprodi di desa Oepuah Utara Kecamatan Biboki Moenleu. Harga benih sawi Rp. 20.000,-/bungkus, sedangkan harga pupuk urea sebesar Rp. 2.000,-/Kg. Hasil penelitian diperoleh bahwa biaya pengadaan benih bervariasi antar petani, mulai dari Rp. 40.000,- sampai dengan Rp. 120.000,-, dengan rata-rata sebesar Rp. 88.000/petani atau Rp. 40.000/are. Biaya pengadaan pupuk urea bervariasi antar petani, mulai dari Rp. 10.000,sampai dengan Rp. 30.000,-, dengan rata-rata sebesar Rp. 22.000/petani atau Rp. 10.000 ,-/are

b. Penerimaan Usahatani Sawi

Penerimaan adalah perkalian antara produksi dengan harga jual. Produksi yang dimaksudkan dalam penelitian ini adalah hasil fisik berupa sayur sawi yang dihasilkan dari usahatani sawi dan hasil tersebut dijual. Hasil produksi yang tidak dijual tidak dinyatakan sebagai penerimaan. Sayur sawi yang dijual dinyatakan dalam satuan ikatan, dengan harga per ikatanya Rp. 2.000,-. Penerimaan dari usahatani sawi di lokasi penelitian bervariasi antar petani, mulai dari Rp. 100.000,- sampai dengan Rp. 750.000,-, dengan rata-rata sebesar Rp. 360.000/petani atau Rp.163.636,36,-/are.

c. Pendapatan Usahatani Sawi

Pendapatan usahatani sawi adalah selisih antara penerimaan dari usahatani sawi dengan semua biaya yang dikorbankan dalam usahatani sawi. Hasil penelitian diperoleh jumlah penerimaan dari 30 responden sebesar $\mathrm{Rp}$. 10.800.000,- atau Rp. 360.000,-/responden dan jumlah biaya dari 30 responden sebesar Rp. 3.300.000,- atau Rp. 110.000,-/responden, sehingga pendapatan usahatani sawi di lokasi penelitian dari 30 responden sebesar Rp. 7.500.000,- atau Rp. 250.000/responden.

Hasil penelitian dapat pula disajikan berdasarkan rata-rata luasan lahan (are). Jumlah penerimaan sebesar Rp. 163,363,36,-/are dan jumlah biaya sebesar Rp. 50.000 ,-/are, sehingga pendapatan usahatani sawi di lokasi penelitian sebesar Rp. 113.636,36,-/are. Pendapatan usahatani sawi secara ringkas ditunjukan pada Tabel 2 .

Tabel 2. Distribusi Pendapatan (Rp) Usahatani Sawi per 30 Responden, per Responden dan per Luas Lahan (Are) di Desa Humusu Oekolo

\begin{tabular}{clrrr}
\hline No & Uraian & $\Sigma$ Biaya (TC) & $\begin{array}{c}\Sigma \text { Penerimaan } \\
(\mathrm{TR})\end{array}$ & \multicolumn{1}{c}{$\begin{array}{c}\Sigma \text { Pendapatan } \\
(\mathrm{Pd}=\mathrm{TR}-\mathrm{TC})\end{array}$} \\
\hline 1 & Per 30 Resp & $3,300,000.00$ & $10,800,000.00$ & $7,500,000.00$ \\
2 & Per Resp & $110,000.00$ & $360,000.00$ & $250,000.00$ \\
3 & Per Are & $50,000.00$ & $163,636.36$ & $113,636.36$ \\
\hline Sumber: & Data Primer & &
\end{tabular}

\subsection{Kelayakan Usahatani Sawi}

Kelayakan usahatani sawi di lokasi penelitian dianalisi menggunakan analisis return cost ratio $(\mathrm{R} / \mathrm{C})$, yaitu perbandingan antara penerimaan total dengan biaya total.

Diketahui penerimaan total sebesar Rp. 10.800.000,00,- dan biaya total sebesar Rp. 3.300.000,00, sehingga R/C sebesar 3,27. Artinya secara ekonomi usahatani sawi di desa Humusu Oekolo secara ekonomi menguntungkan, sehingga layak dilanjutkan, karena biaya mengalami peningkatan sebesar $1 \%$ maka penerimaan akan meningkat sebesar $3,27 \%$.

$\mathrm{R} / \mathrm{C}$ yang diperoleh, sesungguhnya dapat lebih kecil, karena tidak semua korbanan perani dinilai dengan uang sebagai biaya seperti sudah diuraikan di atas.

\section{Simpulan}

Pendapatan usahatani sawi di desa Homusu Oekolo Kecamatan Insana Utara Kabupaten TTU sebesar Rp. 250.000/responden atau sebesar Rp. 113.636,36, /are. RC ratio sebesar 3,27. Artinya secara ekonomi usahatani sawi di desa Humusu Oekolo secara ekonomi menguntungkan, sehingga layak dilanjutkan, karena biaya mengalami peningkatan sebesar $1 \%$ maka penerimaan akan meningkat sebesar $3,27 \%$. RC ratio yang diperoleh, sesungguhnya dapat lebih kecil atau dapat lebih besar lagi, karena tidak semua korbanan perani dinilai dengan uang sebagai biaya seperti sudah diuraikan di atas dan tidak semua produksi dinyatakan sebagai penerimaan.

\section{Pustaka}

BPS Kab. TTU, 2007. Timor Tengah Utara Dalam Angka. BPS Kab. TTU. Kefamenanu.

BPS Kab. TTU, 2008. Timor Tengah Utara Dalam Angka. BPS Kab. TTU. Kefamenanu.

BPS Kab. TTU, 2009. Timor Tengah Utara Dalam Angka. BPS Kab. TTU. Kefamenanu.

BPS Kab. TTU, 2010. Timor Tengah Utara Dalam Angka. BPS Kab. TTU. Kefamenanu.

BPS Kab. TTU, 2011. Timor Tengah Utara Dalam Angka. BPS Kab. TTU. Kefamenanu.

Hernanto. F., 1993. Ilmu Usahatani. Penebar Swadaya. Jakarta.

Mubyato, 1989. Pengantar Ekonomi Pertanian. LP3ES. Jakarta.

Soeharjo, A., dan D. Patong, 1973. Sendi-Sendi Pokok Ilmu Usahatani. Depertemen Ilmu-Ilmu Sosial Ekonomi. IPB, Bogor.

Soekartawi, 1993. Analisis Usahatani. Universitas Indonesia. Jakarta.
Sunarjono. H., 2002. Seri Agribisnis: Bertanam 30 Jenis Sayur. Penebar Swadaya.

Tohir. K.A., 1983. Seuntai Pengetahuan Usahatani. Rineka Cipta. Jakarta. 